\title{
Cultured gill-derived Neoparamoeba pemaquidensis fails to elicit amoebic gill disease (AGD) in Atlantic salmon Salmo salar
}

\author{
R. N. Morrison ${ }^{1, *}$, P. B. B. Crosbie' ${ }^{1}$, M. T. $\operatorname{Cook}^{2}$, M. B. Adams ${ }^{1}$, B. F. Nowak ${ }^{1}$ \\ ${ }^{1}$ Aquafin CRC, School of Aquaculture, University of Tasmania, Launceston, Tasmania 7250, Australia \\ ${ }^{2}$ Aquafin CRC, Integrated Sustainable Aquaculture, CSIRO Marine Research, GPO Box 1538, Hobart, \\ Tasmania 7000, Australia
}

\begin{abstract}
Amoebic gill disease (AGD) affects the culture of Atlantic salmon Salmo salar in the southeast of Tasmania. The disease is characterised by the presence of epizoic Neoparamoeba spp. in association with hyperplastic gill tissue. Gill-associated amoebae trophozoites were positively selected by plastic adherence for culture in seawater, where they proliferated using heat-killed E. coli as a nutrient source. One isolate of gill-harvested amoebae designated NP251002 was morphologically consistent to $N$. pemaquidensis under light, fluorescence and transmission electron microscopy. Rabbit anti-N. pemaquidensis antiserum bound to NP251002, and N. pemaquidensis small subunit (SSU) ribosomal DNA (18S rDNA) was detected in NP251002 genomic DNA preparations using PCR. A high degree of similarity in the alignment of the NP251002 18S rDNA PCR amplicon sequence with reference isolates of $N$. pemaquidensis suggested conspecificity. While short-term culture $(72 \mathrm{~h})$ of gill-harvested amoebae does not affect the capacity of amoebae to induce AGD, Atlantic salmon challenged with NP251002 after the trophozoites had been 34 and $98 \mathrm{~d}$ in culture exhibited neither gross nor histological evidence of AGD. It is not known if NP251002 were avirulent at the time of isolation, had down-regulated putative virulence factors or virulence was inhibited by the culture conditions. Therefore, the time in culture could be a limiting factor in maintaining virulence using the culture technique described here.
\end{abstract}

KEY WORDS: Amoebic gill disease $\cdot$ Neoparamoeba pemaquidensis · Atlantic salmon Resale or republication not permitted without written consent of the publisher

\section{INTRODUCTION}

Amoebic gill disease (AGD) affects Atlantic salmon Salmo salar L. (reviewed by Munday et al. 2001), rainbow trout Oncorhynchus mykiss Walbaum (Munday et al. 1993), coho salmon Oncorhynchus kisutch Walbaum (Kent et al. 1988), turbot Scophthalmus maximus L. (Dyková et al. 1995, 1999) and seabass Dicentrarchus labrax L. (Dyková et al. 2000) during mariculture. AGD has persistently affected Atlantic salmon cultured at marine farms in southeastern Tasmania, Australia. The cost of treatment (freshwater bathing) and performance constraints due to AGD imposes a substantial impact on production, and research is being undertaken to reduce the burden of this dis- ease. AGD is characterised by the presence of amphizoic Neoparamoeba spp. on the secondary gill lamellae, and a subsequent hyperplastic response of juxtaposed host tissue. At the cellular level, this response is dominated by proliferation of epithelial cells and mucous cells. There is also an accumulation of leucocytes within the central venous sinus and AGD lesions themselves, indicative of a broader inflammatory response (Adams \& Nowak 2003).

AGD can be initiated in the laboratory by (1) cohabitation of AGD-affected Atlantic salmon with naïve Atlantic salmon (Munday et al. 2001), (2) inoculation of naïve Atlantic salmon with crude gill preparations from AGD-affected Atlantic salmon (Zilberg et al. 2001) or (3) inoculation of naïve Atlantic salmon with 
partially purified amoebae trophozoites from AGDaffected Atlantic salmon (Morrison et al. 2004). However induction of AGD in fish with cultured amoebae has been widely unsuccessful (Kent et al. 1988, Howard et al. 1993, Findlay 2001). Therefore, AGD research in our laboratory is constrained by the necessity to maintain a tank of AGD-affected fish for access to wild-type (virulent) amoebae.

During early work on AGD in Tasmania, a number of Neoparamoeba pemaquidensis clones were isolated from Atlantic salmon (T. Howard, Fish Health Unit, Department of Primary Industries, Water and Environment, Mount Pleasant, Launceston, Tasmania). However, all but one (PA-027) have senesced. In our laboratory, recent efforts to culture amoebae from the gills of AGD-affected salmon have been unsuccessful. Therefore, a recently described method was utilised to isolate gill-associated Neoparamoeba spp. (Morrison et al. 2004) and to culture new isolates of gill-associated amoebae, including $N$. pemaquidensis, that are potentially virulent. One such strain described here (NP251002) was used to inoculate systems housing Atlantic salmon; however, it failed to elicit AGD. Together, these observations question the relevance of current culture techniques in the context of AGD research and provide further impetus for efforts to create a culture environment that supports the growth of virulent $N$. pemaquidensis.

\section{MATERIALS AND METHODS}

Isolation and culture of amoebae. Atlantic salmon Salmo salar (approximately $100 \mathrm{~g}$ ) were obtained from an experimental AGD infection tank at the School of Aquaculture, University of Tasmania, Launceston, Tasmania, Australia, and euthanised with an overdose of Aqui-S, as described by the manufacturer (Aqui-S, New Zealand). Isolation of amoebae trophozoites was performed, as described by (Morrison et al. 2004). Viability of amoebae was assessed by trypan blue exclusion, and they were enumerated using a haemocytometer.

Amoebae (60 amoebae $\mathrm{ml}^{-1}$ ) were resuspended in sterile seawater (SS) with $5.5 \times 10^{8}$ heat-killed E. coli $\mathrm{ml}^{-1}$ (ATCC strain 25922) and streptomycin sulphate $(0.001 \%)$ (Sigma), benzylpenicillin (0.001\%) (CSL), carbenicillin $(0.001 \%)$ (Sigma), ampicillin (0.0025\%) (Sigma), erythromycin $(0.001 \%)$ (Sigma), sulphadiazine $(0.63 \%)$ (Sigma) and trimethoprim (0.13\%) (Sigma). Amoebae were dispensed into T25 tissue culture flasks (Nunc) (10 ml total volume) and incubated at $18^{\circ} \mathrm{C}$ in atmospheric conditions. Amoebae were passaged weekly by the addition of heat-killed E. coli $\left(5.5 \times 10^{8} \mathrm{ml}^{-1}\right)$ or subcultured.
Validation of trophozoite identity. Amoebae were prepared for light microscopy by placing a $20 \mu \mathrm{l}$ aliquot of cells on a glass coverslip for $30 \mathrm{~min}$ at room temperature. Non-adherent cells were washed off the coverslip and the cells were viewed using a phase contrast inverted microscope.

For transmission electron microscopy, NP251002 culture flasks were washed with SS and the amoebae fixed in situ with $3 \%$ glutaraldehyde in $200 \mathrm{mM}$ cacodylate/seawater buffer. Amoebae were post-fixed in $1 \%$ osmium tetroxide, dehydrated with an increasing gradient of acetone and embedded in Spurr's resin. Ultrathin sections were viewed using a Jeol JEM 1010 electron microscope at $60 \mathrm{kV}$.

Polyclonal rabbit anti-Neoparamoeba pemaquidensis (PA-027) antiserum was produced according to a protocol developed for the production of polyclonal antisera used in routine diagnostic analyses of AGD (Fish Health Unit, Department of Primary Industries, Water and Environment, Mount Pleasant Laboratories, Launceston, Tasmania). In this instance, the antisera had been partially characterised by Douglas-Helders et al. (2001) using an immunofluorescent antibody test (IFAT). Subsequent analysis of antiserum specificity utilised an immunoperoxidase assay on various nontarget amoeba species (Table 1). Positive control amoeba smears (PA-027; Department of Primary Industries, Water and Environment, Launceston, Tasmania) were used throughout specificity studies. Sensitivity of the antiserum in immunocytochemical staining was determined empirically and the optimum working dilution was 1:500.

Immunocytochemical staining was performed according to (Bridle et al. 2003). Briefly, amoebae were smeared onto glass microscope slides, dried and heat fixed. Cells were rehydrated with phosphate buffered saline (PBS), blocked with normal goat serum (10 min at $20^{\circ} \mathrm{C}$ ) and rabbit anti-PA027 antiserum was added (1:500 in PBS $/ 0.1 \% \mathrm{BSA})$ for $30 \mathrm{~min}$ at $37^{\circ} \mathrm{C}$. An immunoperoxidase (Vectastain, Vector laboratories) antirabbit IgG kit was used for detection, as specified by the manufacturer's instructions. Cell preparations were incubated with a biotinylated goat anti-rabbit antibody for a further $30 \mathrm{~min}$ at $37^{\circ} \mathrm{C}$. ABC (avidinbiotin-peroxidase) complex was added for $30 \mathrm{~min}$ at room temperature, and the positive cells were visualised by the addition of diaminobenzidine and urea/peroxide (Roche Diagnostics).

Alternatively, amoebae were harvested from culture flasks and incubated with the rabbit anti-PA-027 antiserum (1:50 in PBS) for $30 \mathrm{~min}$ at $4^{\circ} \mathrm{C}$. A FITC conjugated goat anti-rabbit antibody (1:100, Fab'2 fragment IgG, H \& L chains, Jackson Immunotech) was added for a further $30 \mathrm{~min}$ at $4^{\circ} \mathrm{C}$. Cells were washed 3 times with PBS after each step. Finally, cells were resuspended in 
Table 1. Rabbit polyclonal anti-PA-027 binds to Neoparamoeba pemaquidensis and loosely related species of Paramoeba. IFAT: indirect fluorescent antibody test; IP: immunoperoxidase test

\begin{tabular}{|c|c|c|c|}
\hline Species & Source of culture & IFAT/IP result & Original source \\
\hline Paramoeba pemaquidensis & ATCC 30735 & $+^{\mathrm{a}}$ & Seawater, USA \\
\hline P. pemaquidensis & ATCC 50172 & $+^{\mathrm{a}}$ & Coho salmon, USA \\
\hline P. eilhardi & CCAP $1560 / 2$ & $-{ }^{a}$ & Seawater, France \\
\hline Neoparamoeba pemaquidensis & CCAP $1560 / 4 \& 2$ & $+^{\mathrm{a}}$ & Seawater, Wales \\
\hline N. aesturina & CCAP $1560 / 7$ & $+^{\mathrm{a}}$ & Seawater, Portugal \\
\hline Pseudoparamoeba pagei & CCAP 1566/1 & $+^{\mathrm{a}}$ & Seawater, England \\
\hline Platyamoeba spp. & Amoebae collection at DPIWE, Tas. & - & Atlantic salmon, Nubeena, Tasmania \\
\hline Vanella or Platyamoeba spp. & Amoebae collection at DPIWE, Tas. & - & Isopod, Dover, Tasmania \\
\hline Flabellula spp. & Amoebae collection at DPIWE, Tas. & - & Unknown \\
\hline Heteroamoeba spp. & Amoebae collection at DPIWE, Tas. & - & Marine environment, Tasmania \\
\hline Acanthamoeba spp. & Amoebae collection at DPIWE, Tas. & - & Atlantic salmon, Dover, Tasmania \\
\hline
\end{tabular}

FACSFix ( $2 \%$ glucose, $0.4 \%$ formalin and $0.02 \% \mathrm{NaN}_{3}$ in PBS) for analysis using a Coulter EPICS Elite ESP flow cytometer. Listmode data were analysed using Win MDI 2.8 software (Joseph Trotter, Scripps Research Institute, La Jolla, California, USA).

Detection of Neoparamoeba pemaquidensis SSU rDNA by PCR and nucleotide sequencing of PCR amplicons. DNA was extracted from amoebae using bacterial DNA extraction (Wilson \& Carson 2001). Detection of $N$. pemaquidensis 18S rDNA was performed using PCR according to Wong et al. (2004). Briefly, $2 \mu \mathrm{l}\left(10 \mathrm{ng} \mathrm{l}^{-1}\right)$ genomic DNA from NP251002, PA-027, or E. coli (ATCC strain 25922) was added to $2 \mu \mathrm{l} 10 \times$ PCR buffer (Invitrogen Life Technologies), $1.6 \mu \mathrm{l}(2.5 \mathrm{mM}) \mathrm{dNTP}$ (Epicentre Technologies), $0.8 \mu \mathrm{l}$ $(2 \mathrm{mM}) \mathrm{MgCl}_{2}, 0.6 \mu \mathrm{l}(0.3 \mathrm{mM})$ each of $10 \mu \mathrm{M}$ forward (fNp-Hxe23b1; 5'-GTGAGTGATGAGTAGACCTACTGG-3') and reverse (rNp-Hx49; 5'-CACAACAAACTCGCTCTACCCG-3') primers respectively, $0.2 \mu \mathrm{l}$ (1 U) Platinum Taq DNA polymerase (Invitrogen Life Technologies), $1 \mu \mathrm{l}$ BSA (20 ng per reaction) and water to a total volume of $20 \mu$ l. Amplification conditions consisted of 1 cycle of $94^{\circ} \mathrm{C}$ for $3 \mathrm{~min}, 35$ cycles of $94^{\circ} \mathrm{C}$ for $45 \mathrm{~s}, 58^{\circ} \mathrm{C}$ for $45 \mathrm{~s}$ and $72^{\circ} \mathrm{C}$ for $45 \mathrm{~s}$ followed by 1 cycle of $72^{\circ} \mathrm{C}$ for $4 \mathrm{~min}$. PCR products were assessed using $2 \%$ agarose gels containing ethidium bromide and visualised with a transilluminator.

PCR products were excised from agarose gels. The DNA was extracted using a Qiagen gel extraction kit (Qiagen) and ligated into TOPO-TA cloning vector (Invitrogen Life Technologies). The ligated plasmid was used to transform chemically competent E. coli $\left(\right.$ One Shot $\left.{ }^{\circledR}\right)$. Positive transformants were selected and purified plasmid DNA (QIAprep Miniprep Kit, Qiagen) was restriction digested with EcoRI (New England Biolabs). Sequence analysis of positive clones was performed with an ABI BigDye ${ }^{\mathrm{TM}}$ Terminator Cycle Sequencing kit (Perkin Elmer, Applied Biosystems) using M13 primers (Invitrogen Life Technologies). Sequence data was obtained by running the samples on an ABI 377 automated DNA sequencer (Perkin Elmer, Applied Biosystems).

Identification of amoebae kinetoplastid symbionts by fluorescently staining nucleic acid. Amoebae were harvested from culture flasks, centrifuged and resuspended in SS $(500 \mu \mathrm{l}), 100 \%$ formalin $(15 \mu \mathrm{l})$ and $4^{\prime}, 6-$ diamino-2-phenylindole (DAPI; Sigma, $50 \mathrm{mg} \mathrm{l}^{-1}$; $25 \mu \mathrm{l}$ ) for $30 \mathrm{~min}$ in darkness. Amoebae were placed on a glass microscope slide and observed using a microscope with an ultraviolet light source.

Experimental inoculation of Atlantic salmon with amoebae and assessment of AGD by routine histology. Seawater-adapted Atlantic salmon (approximately $80 \mathrm{~g}$ ) were placed into autonomous recirculating systems consisting of three 801 tanks per system (2 fish $\operatorname{tank}^{-1}$ ). Water was maintained at 16.0 to $16.5^{\circ} \mathrm{C}$ and a $25 \%$ water change was performed approximately every second day. Three independent inoculations were performed (Table 2).

Fish were euthanised as described earlier (see 'Isolation and culture of amoebae') and the gills were excised and placed in seawater Davidson's fixative for a minimum of $1 \mathrm{~h}$. Gills were then transferred to $70 \%$ ethanol until the second left gill arch was processed for routine histology. Gills were sectioned (5 $\mu \mathrm{m})$ and either H \& E or alcian blue/periodic acid Schiff's stained.

\section{RESULTS}

\section{Proliferation of trophozoites}

In the absence of any recent success in developing new culturable clones of Neoparamoeba pemaquidensis in our laboratory it was necessary to develop simple methods to purify crude gill preparations of amoebae 

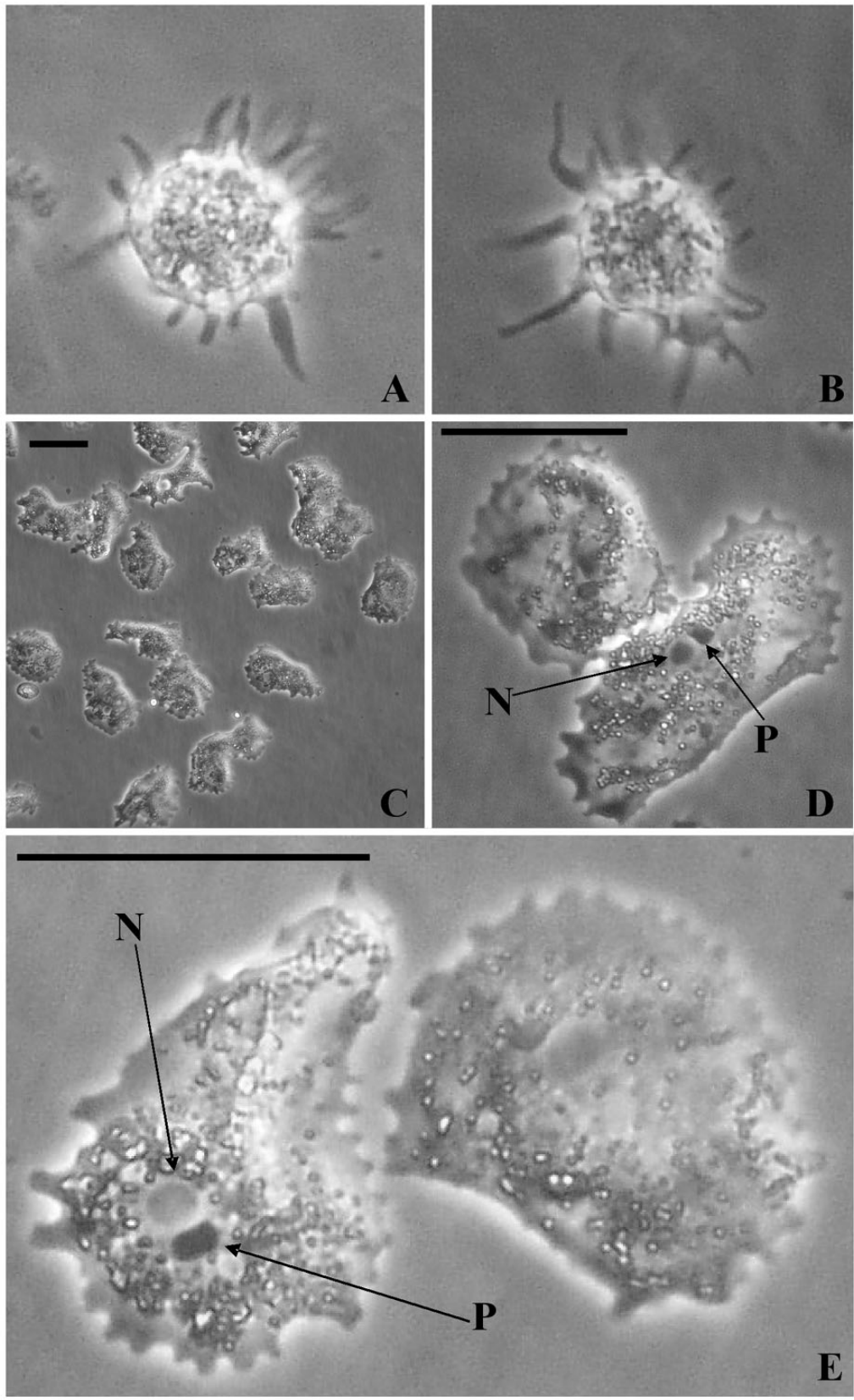

Fig. 1. (A,B) Free-floating and (C-E) plastic-adhered trophozoites of amoebae isolated from the gills of amoebic gill disease (AGD)-affected Atlantic salmon. Free-floating amoebae possess digitiform pseudopodia. Upon adherence to plastic, amoebae flatten and exhibit mamilliform subpseudopodia. Both the nucleus $(\mathrm{N})$ and the parasome $(\mathrm{P})$ are clearly evident after adherence.

Images were taken using an inverted microscope with phase contrast. Scale bars $=40 \mu \mathrm{m}$

Table 2. Details of amoebae culture and inoculation duration

\begin{tabular}{|llccrc|}
\hline Inoculation & Amoebae & $\begin{array}{c}\text { Duration of } \\
\text { amoebae culture (d) }\end{array}$ & $\begin{array}{c}\text { Number of } \\
\text { passages }\end{array}$ & $\begin{array}{c}\text { Concentration of } \\
\text { amoebae (cells l-1) }\end{array}$ & $\begin{array}{c}\text { Duration of } \\
\text { inoculation (d) }\end{array}$ \\
\hline 1 & NP251002 & 34 & 4 & 5020 & 14 \\
2 & NP251002 & 98 & 14 & 59000 & 19 \\
3 & Total amoebae ${ }^{\mathrm{a}}$ & 3 & 1 & 3160 & 8 \\
\end{tabular}


(trophozoites) for ongoing studies of AGD. Cellular adherence is routinely used in ex vivo cell purification systems to negatively or positively select glass/plastic adherent populations of cells such as macrophages or eosinophilic granulocytes. N. pemaquidensis is adherent to net negatively charged surfaces (Martin 1987), and recent work in our laboratory demonstrated that amoebae (trophozoites) harvested from gills of AGD infected Atlantic salmon are plastic adherent (Morrison et al. 2004).

Once dissociated from host tissue, freefloating amoebae possessed digitiform, nonfurcated hyaline pseudopodia that protruded from an almost spherical cell (Fig. 1A,B). Upon initiation of contact with petri dishes, a marked cytoskeletal rearrangement took place. Amoebae flattened, with a transition from digitiform to lobed mamilliform dactylopodia, and an often exaggerated hyaloplasm appeared, probably a result of cytoskeletal rearrangement during locomotion. At higher magnification, the trophozoite nucleus and parasome(s) were clearly evident (Fig. 1D,E), although the numbers of symbionts were variable. When placed in culture flasks with heat-killed E. coli as a nutrient source, amoebae (trophozoites) consistently proliferated (100\% of attempts), although the rate of division was highly variable (data not shown).

\section{Characterisation of trophozoites}

Efforts were undertaken to develop new cultured isolates of amoebae (trophozoites) harvested from AGD infected Atlantic salmon. One strain of amoebae, designated NP251002, grew relatively quickly ( 1 division $\mathrm{d}^{-1}$ ) in xenic culture (unidentified bacterial contamination). NP251002 was hypothesised to be predominantly if not exclusively Neoparamoeba pemaquidensis and therefore targeted for further characterisation. Under phase contrast microscopic conditions, NP251002 possesses morphological features consistent with amoebae of the genus Neoparamoeba (Page 1983). The kinetoplastid endosymbiont (parasome) (Dyková et al. 2003) was observed using light microscopy (Fig. 2C,D) and later confirmed in $100 \%$ of cells observed by fluorescently labelling nucleic acid with DAPI (Fig. 2E,F). Similarly, the parasome was observed in all cells assessed by transmis- sion electron microscopy, restricting the identity of NP251002 to 3 genera: Paramoeba, Neoparamoeba and Janickina. However, NP251002 possessed a thin glycocalyx of variable thickness, consistent with the genus Neoparamoeba (Fig. 3).

Polyclonal rabbit anti-PA-027 antiserum bound to $100 \%$ of NP251002 in immunocytochemical analyses and almost $100 \%$ of NP251002 in flow cytometric analyses (Fig. 4). While the binding of this antiserum is consistent with our hypothesis that NP251002 is indeed
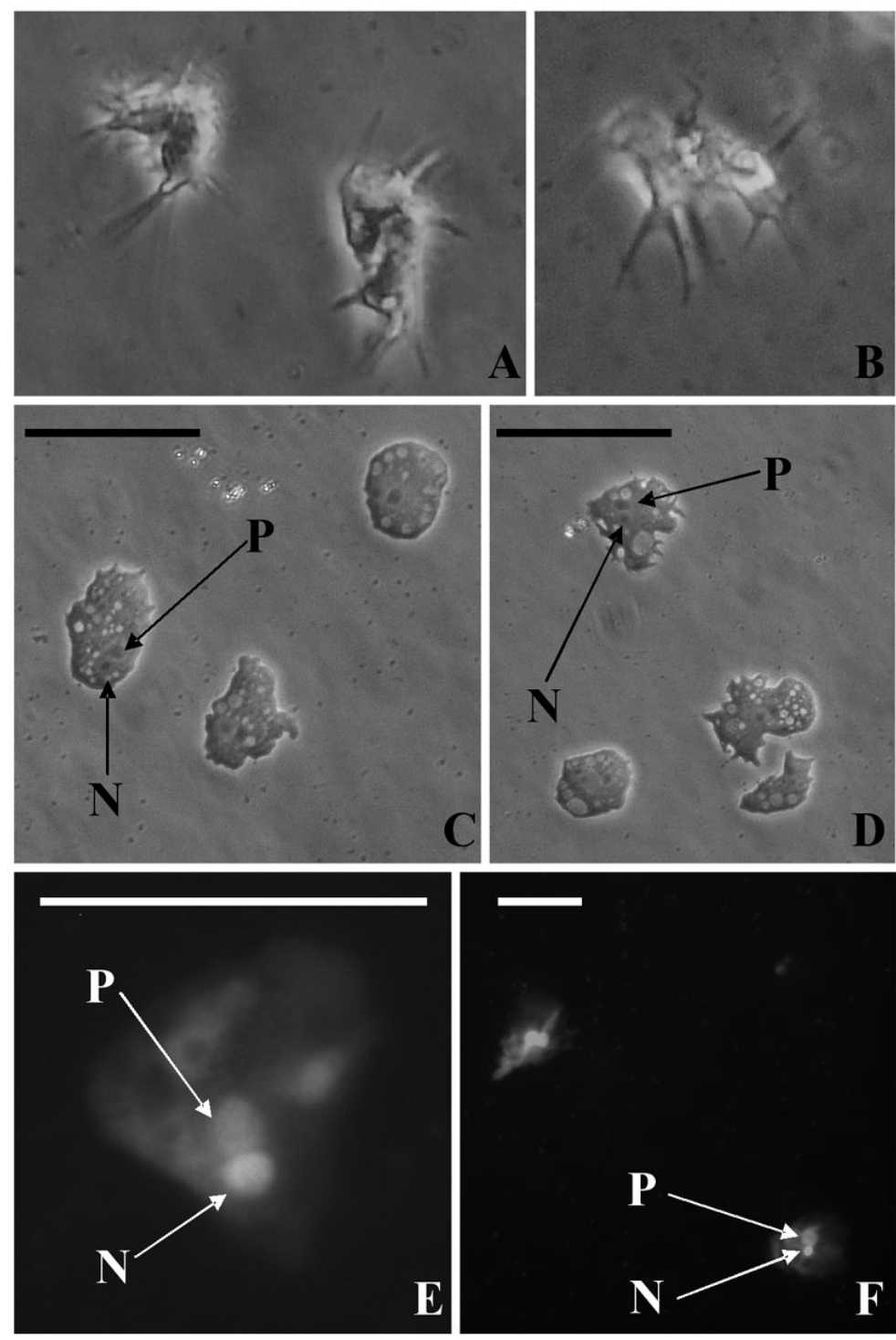

Fig. 2. Cultured Neoparamoeba pemaquidensis strain NP251002 is smaller than freshly isolated gill-associated amoebae but retains the basic morphological characteristics of Neoparamoeba. (A,B) Free-floating NP251002. (C,D) Observation of the nucleus (N) and parasome (P) of NP251002 by light microscopy. (E,F) Confirmation of the nucleus and parasome by DAPI staining of nuclei acid. Images were taken using (A-D) an inverted microscope with phase contrast and $(\mathrm{E}, \mathrm{F})$ a compound microscope with fluorescence. Scale bars $=40 \mu \mathrm{m}$ 

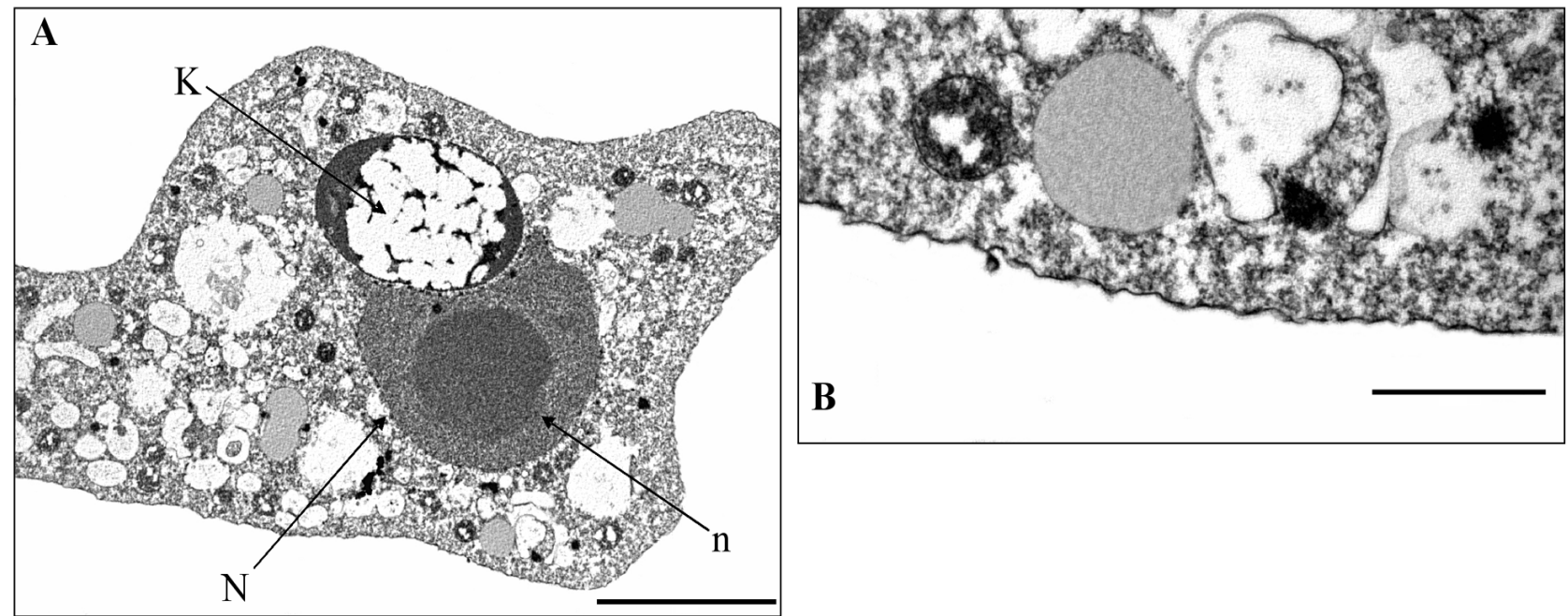

Fig. 3. The ultrastructure of NP251002 is consistent with Neoparamoeba pemaquidensis. (A) The nucleus (N) and nucleolus (n) are prominent, as is the kinetoplastid endosymbiont (parasome). (B) The glycocalyx of an NP251002 trophozoite with irregular thickness. Note absence of microscales. Scale bars $=$ (A) $5 \mu \mathrm{m}$ and (B) $1 \mu \mathrm{m}$
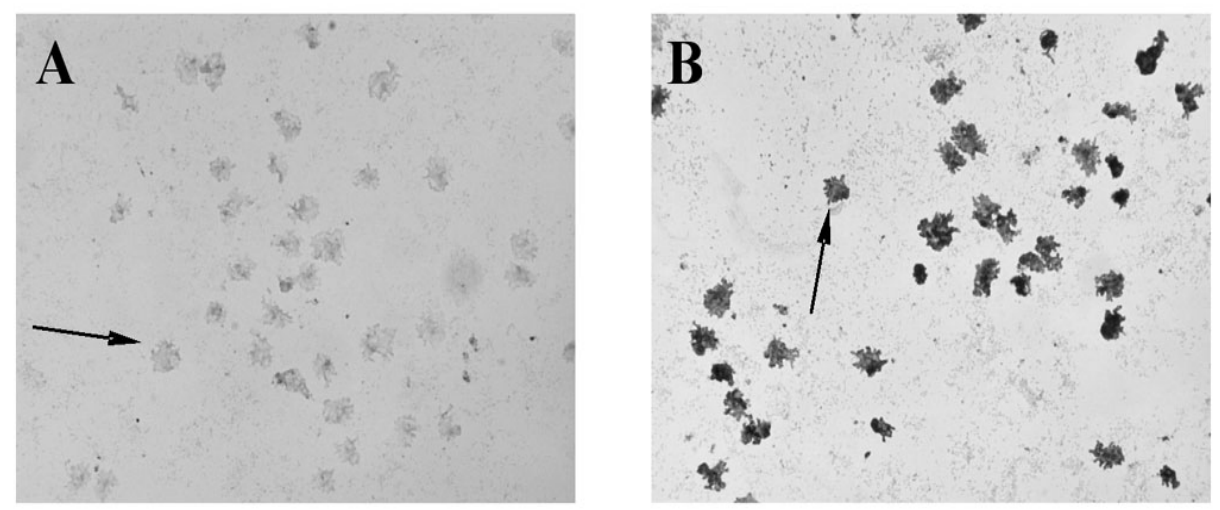

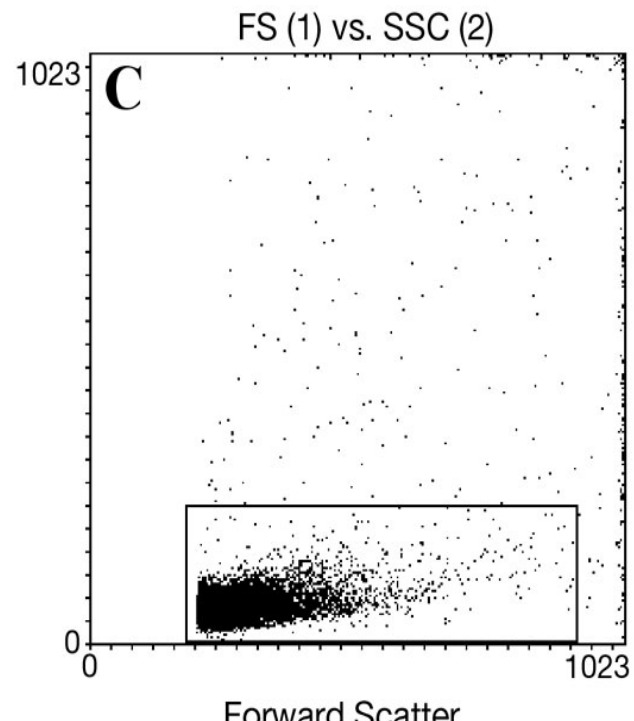

Forward Scatter

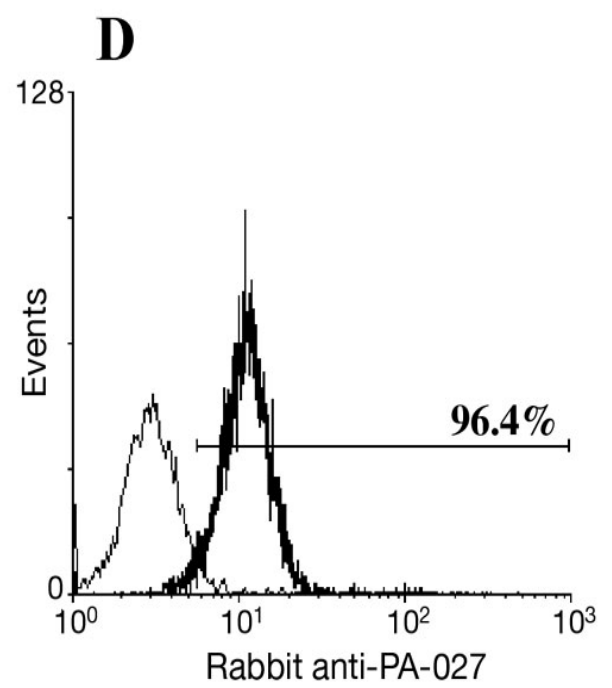

Fig. 4. Rabbit anti-PA027 antiserum binds to all cultured NP251002. (A,B) Qualitative assessment of binding by immunocytochemistry using biotin/strepavidin-peroxidase for detection. (C,D) Quantitative assessment of binding by flow cytometry (fluorescence) showing (C) the flow cytometric light scattering profile and the gate used to generate the frequency histogram shown in (D). Normal rabbit serum was used as a negative control in both assays 
Neoparamoeba pemaquidensis, the specificity of this antiserum in discriminating amoebae at the species level is questionable (Table 1). However, crossreactivity of the anti-PA027 serum is limited to species of amoebae that are not typically associated with the gills of AGD-affected Atlantic salmon (Table 1) and thus antibody binding to amoebae harvested from the gills of Atlantic salmon is interpreted as antibody binding to $N$. pemaquidensis.

Small subunit (SSU) rRNA PCR amplification of NP251002 DNA extracts produced an approximately $1.25 \mathrm{~kb}$ amplicon corresponding to that amplified from the PA-027 genomic DNA positive control (Fig. 5). Moreover, the extracts of $E$. coli genomic DNA, Atlantic salmon genomic DNA (irrelevant DNA control) and no-template DNA control were not amplified using the SSU primer pair (Fig. 5; lanes 4,6 and 5, respectively). The rRNA PCR result was confirmed in an independent laboratory, and these amplicons were excised from an agarose gel, cloned and sequenced. The partial NP251002 SSU rRNA sequence shared a high degree of similarity with other Neoparamoeba pemaquidensis (98\%) and N. aesturina (94\%) species.

Considering the characterisation elements together, the data suggest that NP251002 is Neoparamoeba pemaquidensis, although, without having performed a cloning process prior to the inoculation of salmon, the presence of a small number of other amoebae cannot be discounted.

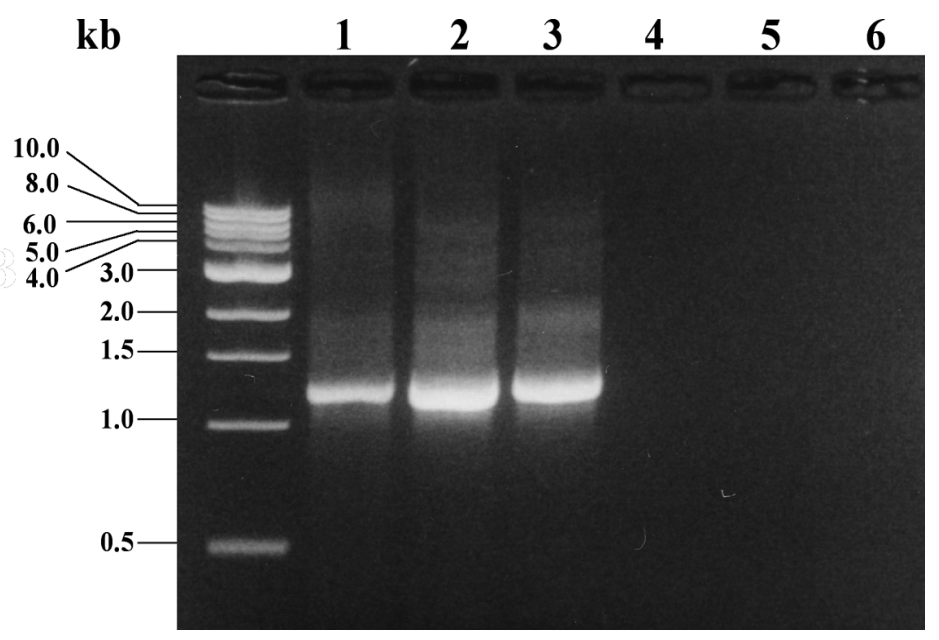

Fig. 5. The 18S rDNA PCR amplification product of NP251002 DNA corresponds to that of the Neoparamoeba pemaquidensis amplicon (1.25 kb). DNA from PA-027 (lane 1, purified DNA positive control), NP251002 (lane 2), PA-027 (lane 3, DNA extraction positive control), E. coli (lane 4), and an irrelevant DNA control (lane 5, Atlantic salmon DNA) were amplified by PCR using putative $N$. pemaquidensis specific $18 \mathrm{~S}$ rDNA primers. A no template DNA negative control was also included in the assay (lane 6). The DNA ladder fragment sizes are indicated in kilobases $(\mathrm{kb})$

\section{Failure of NP251002 to induce symptoms in Atlantic salmon}

NP251002 were inoculated into fish holding tanks at concentrations well in excess of that routinely used to generate experimental AGD infections (Zilberg et al. 2001, Morrison et al. 2004). In addition, the duration of inoculation was well in excess of the time normally taken to elicit gross signs of AGD in fish kept in the systems described here (pers. obs.). However, neither gross nor histological signs of AGD were detected in fish inoculated with NP251002 after 34 d (4 passages; Fig. 6B,C) or $98 \mathrm{~d}$ (14 passages; Fig. 6E,F) in culture. While a single amoeba was detected in the gills of fish inoculated with NP251002 after 34 d in culture, no host-inflammatory reaction consistent with AGD was observed. The failure of NP251002 to elicit AGD could be interpreted as: (1) the selection of an avirulent strain of Neoparamoeba pemaquidensis; (2) an inoculation period that was too short; (3) the down-regulation of putative virulence factors; or (4) the inhibition of virulence by the culture conditions. To address these issues, at least in part, amoebae were isolated as described (Morrison et al. 2004) and placed in culture with or without $E$. coli for 72 h. These cells were then used to inoculate recirculation systems housing AGD naïve fish. At $8 \mathrm{~d}$ post-inoculation, fish inoculated with amoebae cultured with (6/6 fish) or without (6/6 fish) E. coli displayed gross signs of AGD, which was later confirmed by histology (Fig. 7). Again, negative control fish showed neither gross nor histological signs of AGD.

\section{DISCUSSION}

A detailed process was used to characterise NP251002, given that the morphological characters used to describe Neoparamoeba spp. are identical for each of 3 species belonging to this genus (Dyková et al. 2005). These species are $N$. pemaquidensis, N. aestuarina and the newly described $N$. branchiphila (Dyková et al. 2005). NP251002 is considered to be N. pemaquidensis, using both morphological and molecular characters as support. A partial small subunit (SSU) rRNA gene sequence $(\sim 1.25 \mathrm{~kb})$ was obtained from NP251002 in this study, and in preliminary phylogenetic analyses (maximum likelihood and maximum parsimony methods) the data suggested conspecificity of NP251002 with N. pemaquidensis (data not shown). In a concurrent study, the full length SSU rRNA gene from clonal NP251002 was sequenced and incorporated into a much broader data set for molecular phylogenetic analyses (Dyková et al. 2005). This study describes data consistent with our preliminary analy- 

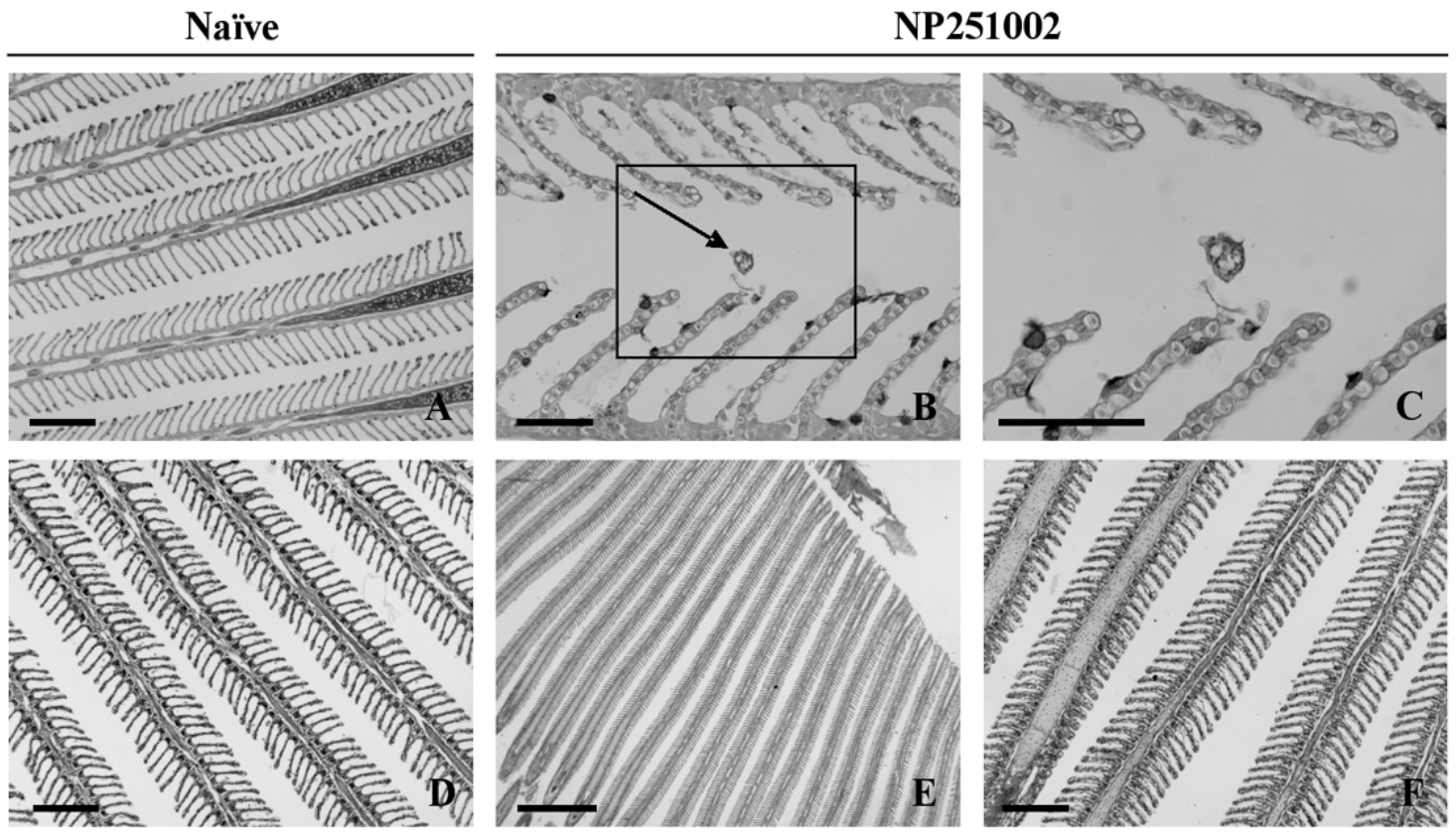

Fig. 6. Salmo salar. Inoculation of fish holding systems with NP251002 failed to elicit histologically detectable signs of AGD in Atlantic salmon at either Day 34 or Day 98 post-harvest. (A,D) AGD naïve fish exhibiting normal histological structure of the gills. (B) A single trophozoite (arrow) on the gill of a fish held in systems inoculated with NP251002 at Day 34 post-harvest; however, the amoeba was not associated with any detectable hyperplastic epithelial tissue. (C) Higher magnification of inset in (B). $(\mathrm{E}, \mathrm{F})$ Normal histological structure of the gills, despite inoculation with NP251002 at Day 98 post-harvest. Scale bars $=(\mathrm{A}, \mathrm{D}, \mathrm{F})$ $200 \mu \mathrm{m},(\mathrm{B}, \mathrm{C}) 50 \mu \mathrm{m}$ and (E) $1000 \mu \mathrm{m}$

ses, suggesting that the NP251002 SSU rRNA sequence clustered together with other sequences obtained from $N$. pemaquidensis clones distinct from 2 other clades containing $N$. aestuarina or $N$. branchiphila. Interestingly, the $N$. branchiphila clones were obtained from isolates of amoebae derived from AGDaffected Atlantic salmon. Therefore, while it is clear that NP251002 is N. pemaquidensis, it is important to note that in the future AGD may be redefined as a disease with mixed aetiology.

Studies on AGD in Tasmania consistently implicate Neoparamoeba pemaquidensis as the pathogen (see review by Munday et al. 2001). However, there are no cultured virulent strains or clones available (Kent et al. 1988, Howard et al. 1993, Findlay 2001). Optimistically, the development of virulent in vitro strains of $N$. pemaquidensis would prelude a significant advance in our understanding of AGD, yet in order to achieve this the use of conventional culture techniques to develop such strains is questionable. Independent studies (Kent et al. 1988, Howard et al. 1993, Findlay 2001), and the results reported here, demonstrate that neither MYA agar nor seawater supplemented with heat-killed bacteria support the growth of virulent $N$. pemaquidensis.

Using the culture technique described here, Neoparamoeba pemaquidensis appears to become avirulent within $4 \mathrm{wk}$ of harvest from the gill of AGD- affected Atlantic salmon, although it was not determined if cells were virulent at the time of isolation. While avirulence of amoebae at the time of isolation cannot be discounted, the cells used to generate the NP251002 were isolated from an experimental AGD infection of Atlantic salmon that had been maintained continuously for over 1 yr. Amoebae isolated from the gills of AGD-affected Atlantic salmon in this system have been used many times to begin autonomous experimental AGD infections (100\% successful) suggesting that NP251002 was likely to have been virulent when first isolated. Indeed the 'loss' of virulence of amoebae during culture has been described previously. For example, in a similar situation to that described here, Paramoeba invadens was cultured in vivo using sea urchins Strongylocentrotus droebachiensis for $5 \mathrm{yr}$ without loss of virulence; however, trophozoites of amoebae maintained in vitro in polyxenic and monoxenic culture displayed some loss of virulence (Jellett \& Scheibling 1988). Similarly, studies on pathogenic amoebae of humans (Naegleria fowleri and Entamoeba histolytica) have shown a loss of virulence during in vitro culture that was restored after passage (Das \& Ghoshal 1976, Wong et al. 1977). Attempts to restore the virulence of NP251002 have so far been unsuccessful (B. Vincent \& R. Morrison unpubl. data) and are the focus of ongoing studies. 

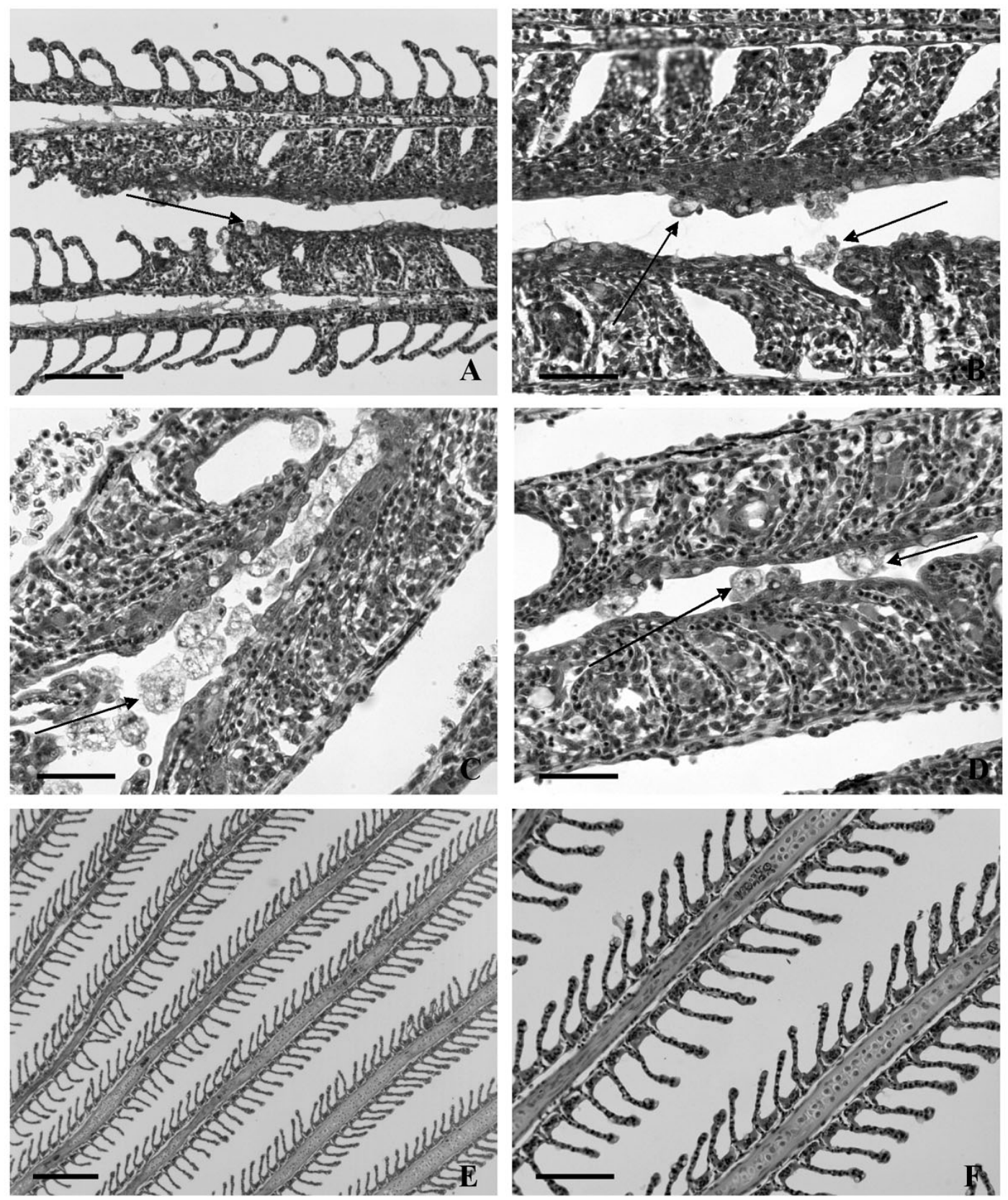

Fig. 7. Short-term incubation of gill-associated amoebae under culture conditions does not affect the pathogenicity of amoebae. The gills of AGD-affected Atlantic salmon were macerated and the total population of amoebae was placed in culture with or without the addition of heat-killed E. coli for $72 \mathrm{~h}$. All Atlantic salmon held in systems inoculated with amoebae cultured $(A, B)$ with or $(C, D)$ without $E$. coli possessed epizoic amoebae juxtaposed to hyperplastic gill tissue consistent with AGD. $(\mathrm{E}, \mathrm{F})$ Gills of AGD-naïve fish exhibiting normal histological structure. Arrows indicate amoebae. Scale bars $=(\mathrm{A}, \mathrm{F}) 100 \mu \mathrm{m}$,

(B-D) $50 \mu \mathrm{m}$ and (E) $200 \mu \mathrm{m}$

In summary, amoebae were isolated from the gills of AGD-affected Atlantic salmon and placed in culture. These cells, designated as NP251002, were identified as Neoparamoeba pemaquidensis and did not elicit AGD in naïve Atlantic salmon. It is not known whether NP251002 was avirulent at the time of isolation, became avirulent under selection pressure during culture or was inhibited during culture, or whether putative virulence factors were downregulated in the absence of key nutritional requirements for virulence or were lacking a stimulus or stimuli that regulate putative virulence factors. 
Acknowledgements. The authors wish to acknowledge support from H. Statham, B. Vincent, M. Attard, Dr. M. DouglasHelders and M. Cozens (UTAS) as well as the contribution from CSIRO and DPIWE. Dr. I. Dyková and technical staff at the Institute of Parasitology, Academy of Science of the Czech Republic, České Budějovice, Czech Republic provided TEM support. This work formed part of a project of Aquafin CRC, and received funds from the Australian Government's CRC Program, the Fisheries R \& D Corporation and other CRC Participants. This project was proudly supported by the 'International Science Linkages' program established under the Australian Government's innovation statement 'Backing Australia's Ability'.

\section{LITERATURE CITED}

Adams MB, Nowak BF (2003) Amoebic gill disease: sequential pathology in cultured Atlantic salmon, Salmo salar L. J Fish Dis 26:601-614

Bridle AR, Butler R, Nowak BF (2003) Immunostimulatory CpG oligodeoxynucleotides increase resistance against amoebic gill disease in Atlantic salmon, Salmo salar L. J Fish Dis 26:367-371

Das SR, Ghoshal S (1976) Resoration of virulence to rat of axenically grown Entamoeba histolytica by cholesterol and hamster liver passage. Ann Trop Med Parasitol 70: 439-443

Douglas-Helders M, Carson J, Howard T, Nowak B (2001) Development and validation of a new dot blot test for the detection of Paramoeba pemaquidensis (Page) in fish. J Fish Dis 24:273-280

Dyková I, Figueras A, Novoa B (1995) Amoebic gill infection of turbot, Scophthalmus maximus. Folia Parasitol 42:91-96

Dyková I, Figueras A, Novoa B (1999) Epizoic amoebae from the gills of turbot Scophthalmus maximus. Dis Aquat Org 38:33-38

Dyková I, Figueras A, Peric Z (2000) Neoparamoeba Page, 1987: light and electron microscopic observations on six strains of different origin. Dis Aquat Org 43:217-223

Dyková I, Fiala I, Lom J, Lukes J (2003) Perkinsiella amoebaelike endosymbionts of Neoparamoeba spp., relatives of the kinetoplastid Ichthyobodo. Eur J Protistol 39:37-52

Dyková I, Nowak BF, Crosbie PBB, Fiala I, Pecková H, Adams MB, Macháãková B, Dvoraková H (2005) Neoparamoeba branchiphila $\mathrm{n}$. sp., and related species of the genus

Editorial responsibility: Wolfgang Körting, Hannover, Germany
Neoparamoeba Page, 1987: morphological and molecular characterisation of selected strains. J Fish Dis 28:49-64

Findlay V (2001) Demonstration and manipulation of acquired resistance to amoebic gill disease in Atlantic salmon, Salmo salar. PhD thesis, University of Tasmania, Launceston

Howard TS, Carson J, Lewis T (1993) Development of a model of infection for amoebic gill disease. In: Valentine P (ed) SALTAS Research and Development Seminar. Hobart, p 103-111

Jellett JF, Scheibling RE (1988) Virulence of Paramoeba invadens Jones (Amoebida, Paramoebidae) from monoxenic and polyxenic culture. J Protozool 35:422-424

Kent ML, Sawyer TK, Hedrick RP (1988) Paramoeba pemaquidensis (Sarcomastigophora: Paramoebidae) infestation of the gills of coho salmon Oncorhynchus kisutch reared in sea water. Dis Aquat Org 5:163-169

Martin RE (1987) Adhesion, morphology, and locomotion of Paramoeba pemaquidensis Page (Amoebida, Paramoebidae): effects of substrate charge density and external cations. J Protozool 34:345-349

Morrison RN, Crosbie PBB, Nowak BF (2004) The induction of laboratory based amoebic gill disease (AGD) revisited. J Fish Dis 27:445-449

Munday BL, Lange $\mathrm{K}$, Foster C, Lester RJG, Handlinger J (1993) Amoebic gill disease of sea-caged salmonids in Tasmanian waters. Tasman Fish Res 28:14-19

Munday BL, Zilberg D, Findlay V (2001) Gill disease of marine fish caused by infection with Neoparamoeba pemaquidensis. J Fish Dis 24:497-507

Page FC (1983) Marine Gymnamoebae. Lavenham Press, Lavenham

Wilson T, Carson J (2001) Rapid, high-throughput extraction of bacterial genomic DNA from selective enrichment culture media. Lett Appl Microbiol 32:326-330

Wong FYK, Carson J, Elliott NG (2004) 18S ribosomal DNAbased PCR identification of Neoparamoeba pemaquidensis, the agent of amoebic gill disease in sea-farmed salmonids. Dis Aquat Org 60:65-76

Wong MM, Karr SL Jr, Chow CK (1977) Changes in the virulence of Naegleria fowleri maintained in vitro. J Parasitol 63:872-878

Zilberg D, Gross A, Munday BL (2001) Production of salmonid amoebic gill disease by exposure to Paramoeba sp. harvested from the gills of infected fish. J Fish Dis 24: $79-82$

Submitted: January 5, 2005; Accepted: March 20, 2005

Proofs received from author(s): August 30, 2005 